\section{Congener-Independent Immunoassay for Microcystins and Nodularins}

\author{
WERNER J. FISCHER, †, \\ IAN GARTHWAITE, $\$$ \\ CHRISTOPHER O. MILES, § \\ KATHRYN M. ROSS, § JAMES B. AGGEN," \\ A. RICHARD CHAMBERLIN," \\ NEALE R. TOWERS, § AND \\ DANIEL R. DIETRICH*,
}

Nestlé Research Center, Nestec Ltd., Vers-chez-les-Blanc, 1000 Lausanne 26, Switzerland, Toxinology and

Food Safety Research, AgResearch Ruakura, Hamilton, Waikato, New Zealand, Department of Chemistry,

University of California, Irvine, California 92697-2025, and Environmental Toxicology, University of Konstanz, D-78457 Konstanz, Germany

Cyanobacteria (blue-green algae) (e.g., Microcystis and Nodularia spp.) capable of producing toxic peptides are found in fresh and brackish water worldwide. These toxins include the microcystin (MC) heptapeptides (>60 congeners) and the nodularin pentapeptides (ca. 5 congeners). Cyanobacterial cyclic peptide toxins are harmful to man, other mammals, birds, and fish. Acute exposure to high concentrations of these toxins causes liver damage, while subchronic or chronic exposure may promote liver tumor formation. The detection of cyc lic peptide cyanobacterial toxins in surface and drinking waters has been hampered by the low limits of detection required and that the present routine detection is restricted to a few of the congeners. The unusual $\beta$-amino acid ADDA (4E,6E3-amino-9-methoxy-2,6,8-trimethyl-10-phenyldeca-4,6-dienoic acid) is present in most $(>80 \%)$ of the known toxic penta- and heptapeptide toxin congeners. Here, we report the synthesis of two ADDA-haptens, the raising of antibodies to ADDA, and the development of a competitive indirect ELISA for the detection of microcystins and nodularins utilizing these antibodies. The assay has a limit of quantitation of $0.02-0.07 \mathrm{ng} / \mathrm{mL}$ (depending on which congeners are present), lower than the WHO-proposed guideline $(1 \mathrm{ng} / \mathrm{mL})$ for drinking water, irrespective of the sample matrix (raw water, drinking water, or pure toxin in PBS). This new ELISA is robust, can be performed without sample preconcentration, detects toxins in freshwater samples at lower concentrations than does the protein phosphatase inhibition assay, and shows very good cross-reactivity with all cyanobacterial cyclic peptide toxin congeners tested to date (MC-LR, - RR, -YR, -LW, -LF, 3-desmethyl-M C-LR, 3-desmethyl-M C-RR, and nodularin).

* Corresponding author telephone: +49-7531-883518; fax: +497531-883170; e-mail: Daniel.Dietrich@uni-konstanz.de.

+ Nestec Ltd.

¥ University of Konstanz.

$\S$ AgResearch Ruakura.

" University of California.
Introduction

Microcystins (MCs) and nodularins (including motuporin) constitute a family of more than 60 structural variants of monocyclic hepta- and pentapeptide toxins (1-3) produced by cyanobacteria of several genera, such as Microcystis, Anabaena, Hapal osi phon, Nodularia, Nostoc, Oscillatoria, and Planktothrix (4). Acute poisoning of humans and animals constitutes the most obvious problem from toxic cyanobacterial blooms (5), in severe cases leading to death (5-7). In a recent incident, 60 patients of a hemodialysis unit in Caruaru, northeast Brazil, died of acute liver failure in February 1996 following acute exposure to toxin-contaminated dialysis water prepared from cyanobacteria-containing lake water (6). In an earlier caseinvolving a massive Anabaena and Microcystisbloom in Itaparica Dam, Brazil, the resulting contamination of drinking water with cyanobacterial toxins was responsible for 2000 cases of acute gastroenteritis and 88 deaths, most of which occurred in children (8). In contrast to the previously well-described acuteintoxications, chronic exposure, although less-well defined, is of even greater concern-especially in view of the high incidence of primary liver cancer in China, which has been attributed to thetumorpromoting effects of chronic consumption of drinking water contaminated with cyanobacterial hepatotoxins (9-11). As a result, there has been much interest in $\mathrm{MC}$ from national and international safety committees, with increasing pressure for stricter regulatory guidelines.

To protect consumers from adverse effects of cyanobacterial peptide toxins, the World Health Organization (WHO) proposed a provisional upper limit for microcystin-LR (MCLR) of $1 \mathrm{ng} / \mathrm{mL}$ in drinking water (12), whereas Health Canada calculated a tolerable daily intake (TDI) of $0.013 \mu \mathrm{g}$ of M C-LR ( $\mathrm{kg}$ of body weight) ${ }^{-1}$ day $^{-1}$ (defined as a $60-\mathrm{kg}$ adult consuming $1.5 \mathrm{~L}$ of water per day, with an MC-LR content of $0.5 \mathrm{ng} / \mathrm{mL}$ water) (13). However, effective consumer protection requires the sensitive and efficient detection of the whole spectrum of cyanobacterial cyclic peptide toxin congeners, many of which are as toxic as MC-LR, and regulation should not be restricted to MC-LR alone. This, however, also requires that the present methods for cyclic peptide toxin analysis be able to quantify the individual congeners with similar sensitivities and at concentrations well below the proposed limits (because the toxic effects of the various congeners are expected to beadditive). The mouse bioassay, routinely used to date, is able to detect toxicity irrespective of the toxin congeners present. However, it has several disadvantages: its sensitivity is quite low, so that it is of use only for the detection of toxin concentrations that could lead to acute intoxications; the intraperitoneal route of administration may not appropriately parallel natural exposures; and many animals and large samples are necessary. The other two widely employed methods, chromatographic detection (e.g., HPLC, HPLC-MS) $(14,15)$ or protein phosphatase inhibition assay $(16,17)$, offer excellent sensitivity but are expensive to perform and require highly skilled personnel or demand extraction and up-concentration of the cyanobacterial mass, associated with problems of recovery and quantification, respectively. While chromatographic methods are capable of detecting and identifying single congeners, routine quantification of all known congeners is almost impossible because new analogues, especially of microcystins, continue to be discovered (18-21). Furthermore, chromatographic methods areill-suited to the detection of toxicity arising from the presence of low levels of several congeners because the concentrations of the individual components may be bel ow the limits of detection. 


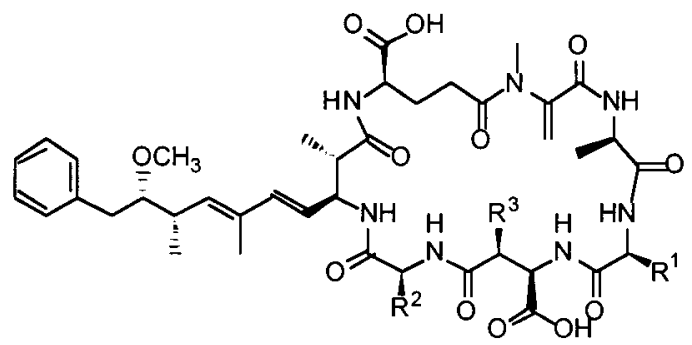

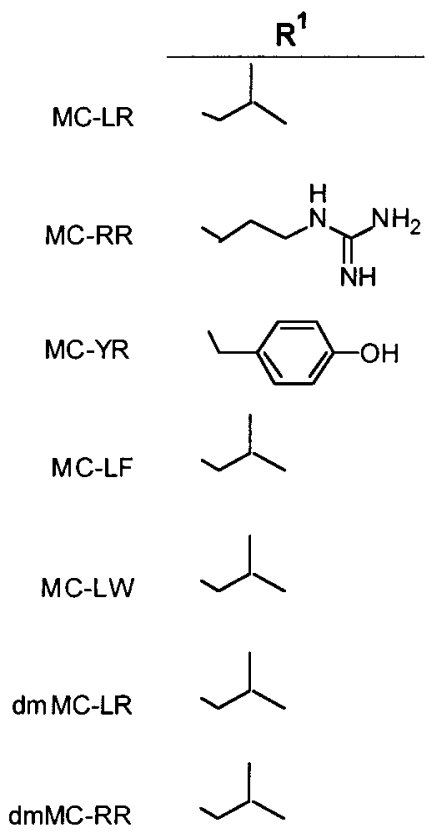

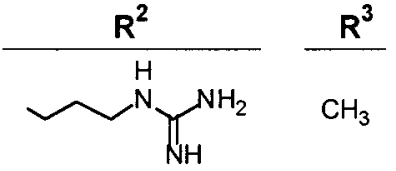<smiles>CCCCNC(=N)N</smiles>

$\mathrm{NH}$<smiles>CCCCNC(=N)N</smiles><smiles>CCc1ccccc1</smiles><smiles></smiles>

H

H<smiles>C/C=C1/C(=O)NC(C(=O)O)C(C)C(=O)N[C@@H](CCCNC(=N)N)C(=O)N[C@@H](/C=C/C(C)=C/[C@H](C)[C@@H](Cc2ccccc2)OC)[C@H](C)C(=O)N[C@@H](C(=O)O)C(=O)N1C</smiles>

Nodularin

FIGURE 1. Chemical structures of microcystins-LR, -RR, -YR, -LF, and -LW, 3-desmethylmicrocystins-LR and -RR, and nodularin.

Because enzyme-linked immunosorbent assays (ELISAs) are quick, cheap, and easy to perform, ELISAs are ideal for the establishment of a screening program-provided that robust assays of sufficient sensitivity and, especially, universal cross-reactivity to the numerous toxin congeners are available. The development of a broad-spectrum ELISA with high sensitivity and broad specificity for cyanobacterial cyclic peptide toxin congeners, and its validation for analysis of water, is therefore a key goal in the establishment of an efficient and cost-effective screening procedure.

Several groups have developed immunoassays for microcystins using monoclonal (22-25) and polyclonal (2628) antibodies. However, all of these antibodies were raised against specific microcystin congeners, and the assays therefore tend to be sensitive to a relatively narrow range of microcystin analogues. Such assays are not ideal for screening because of the possibility of false negatives in the presence of toxic congeners to which the assay is insensitive.

The most commonly encountered congener, microcystinLR (Figure 1), has the structure cyclo-D-alanine-L-leucineerythro- $\beta$-methyl-D-isoaspartic acid-L-arginine-ADDA-Disoglutamic acid- $\mathrm{N}$-methyldehydroalanine (2). The characteristic feature of both microcystins and nodularins (Figure 1) is the presence of $\mathrm{ADDA}$ (4E,6E-3-amino-9-methoxy-2,6,8trimethyl-10-phenyldeca-4,6-dienoic acid) (Figure 2), a hydrophobic $\beta$-amino acid (29). Structural variants of microcystin commonly contain other L-amino acids at two nonconserved sites in the peptide ring. Other structural variantsarise from the presence or absence of methyl groups at the $\beta$-Me-Asp and $\mathrm{N}$-methyldehydroalanine ( $\mathrm{Mdha}$ ) residues, but such changes have little effect on the toxicity of the molecules (30). Isomerization of the ADDA moiety, to form 6Z-ADDA microcystin analogues, however, renders the moleculeessentially nontoxic. Thus, 6E geometry in the ADDA moiety is considered a prerequisite for toxicity in microcystin congeners (31). Approximately $15 \%$ of the known microcystins contain ADDA moieties that are modified by the presence of a hydroxyl or acetoxy (instead of a methoxy) group at C-9. Although such analogues are usually of similar toxicity to their ADDA-containing homologues, they are not common constituents of cyanobacteria and usually co-occur with the more common and abundant unmodified ADDAderived congeners.

An ELISA derived from antibodies recognizing 6E-ADDA, the common structural feature present in thetoxic congeners of microcystins and nodularins, would reduce the total cost of cyanobacterial cyclic peptide toxin analysis and the workload associated with safety testing. It would also minimize the risk of water containing novel but toxic microcystin or nodularin analogues being declared "toxinfree".

Here we report the synthesis of 6E-ADDA analogues for use as haptens, theproduction of antibodies to thesehaptens, and the use of these antibodies in the development of an ELISA for cyanobacterial cyclic peptide toxins. Characterization of the ELISA was performed and the assay validated for analysis of toxic microcystins and nodularins in water. In addition, preliminary experiments were conducted to comparethis new ELISA with the protein-phosphatase inhibition assay (PP assay) for analysis of extracts from lakes and water treatment plants from Switzerland. Thetechnology described in the following paragraphs, as well as the ELISA derived thereof, was submitted for worldwide patenting (PCT WO 01/18059 A2, patent pending). 


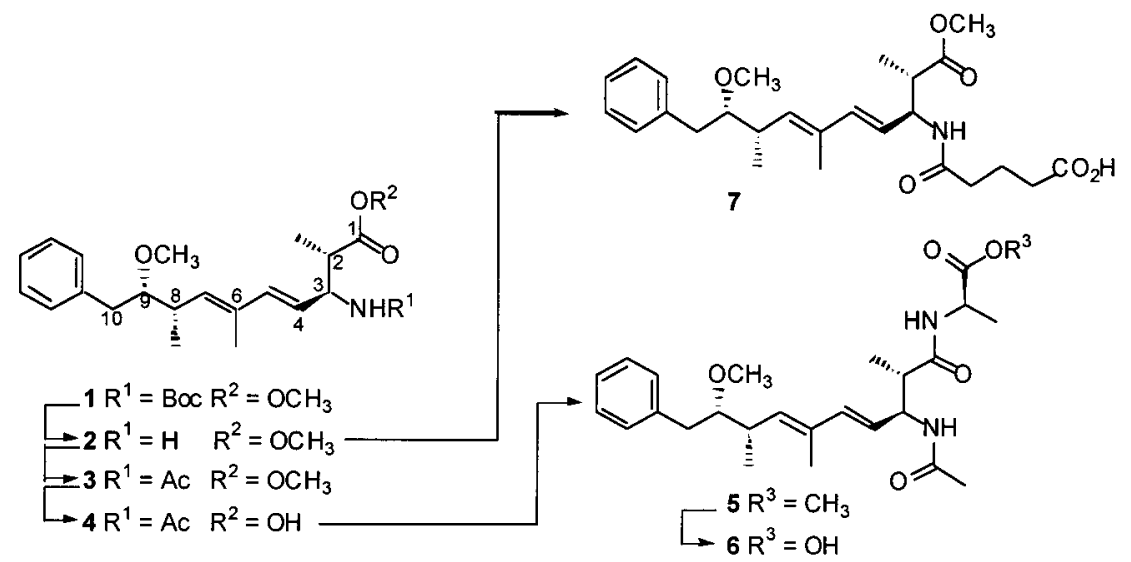

FIGURE 2. Synthesis of the immunizing hapten $N$-acetyl-ADDA-D-alanine (6) and the plate-coating hapten $N$-hemiglutaryl-ADDA methyl ester (7) from $N$-Boc-ADDA methyl ester (1). The structure of ADDA is also show $n$ for comparison along with the atom numbering system for ADDA.

\section{Materials and Methods}

Materials. MC-RR was from Sigma, Germany; MC-LR, MCYR, and nodularin were from Calbiochem, Germany; MCLW and MC-LF were from Alexis, Germany; and 3-desmethylMC-LR (dmMC-LR) and 3-desmethyl-MC-RR (dmMC-RR) (32) were provided by Dr. Jussi Meriluoto (Åbo Akademi University, Turku, Finland). N,N-Carbonyldiimidazole and ovalbumin (OVA) were from Sigma, St. Louis, MO. Bovine serum albumin (BSA) was from Life Technologies, New Zealand. Anti-sheep secondary antibody was from ICN, Germany. 3,3',5,5'-tetramethylbenzidine (TMB) was from Roche, Germany. Tween 20 was purchased from Roth, Germany. Cationized BSA (cBSA) was prepared by coupling diethylamine to BSA by means of 1-ethyl-3-(3-dimethylaminopropyl)carbodiimide (EDAC) (33).

Hapten Synthesis. The hapten used for theimmunization, $\mathrm{N}$-acetyl-D-alanyl-ADDA (6), was synthesized (Figure 2) from the previously reported (34) N-Boc-ADDA methyl ester (1) by replacing the Boc group with acetyl, followed by hydrolysis of the methyl ester and coupling of the resultant free acid group with alaninemethyl ester. Saponification of the alanine methyl ester group gave $\mathbf{6}$, suitable for carboxyl activation and coupling to the carrier protein. The hapten used for the plate-coater, N-hemiglutaryl-ADDA methyl ester (7), was similarly synthesized (Figure 2 ) from $\mathbf{1}$ by replacement of the Boc group with hemiglutaryl.

${ }^{1} \mathrm{H}$ NMR spectra were obtained on an Omega 500 (500 $\mathrm{MHz})$, a General Electric GN-500 (500 M Hz), or a Bruker DRX $(400 \mathrm{MHz})$ spectrometer, and chemical shifts are reported relative to internal tetramethylsilane. Data (at 500 MHz unless specified) are reported asfollows: chemical shift [integral, multiplicity (s, singlet; d, doublet; t, triplet; q, quartet; $\mathrm{m}$, multiplet), coupling constant]. Multiplicitiesand coupling constants for each resonance are recorded in numerical order. Infrared (IR) spectra were obtained with a Perkin-Elmer model 1600 series FTIR spectrophotometer. High-resolution mass spectra were obtained at the $\mathrm{UCI}$ Mass Spectrometry Center with a Micromass Autospec spectrometer. Melting points (mp) were obtained with a Laboratory Devices MelTemp melting point apparatus and are reported uncorrected. Thin-layer chromatography (TLC) was performed on 0.25$\mathrm{mm}$ Merck precoated silica gel plates (60 F-254), and flash chromatography was performed using ICN 200-400 mesh silica gel. Normal-phase preparative HPLC was conducted with a $25 \times 100 \mathrm{~mm}$ Waters prep Nova-Pak HR silica cartridge (WAT038511), and reversed-phase preparative HPLC was conducted with a $25 \times 100 \mathrm{~mm}$ Waters prep Nova-Pak HR $\mathrm{C}_{18}$ cartridge (WAT038510). Reversed-phase analytical HPLC was conducted with a $4.6 \times 250 \mathrm{~mm}$ Rainin Microsorb-MV
$\mathrm{C}_{18}$ column (86-200-C5). Solution $\mathrm{pH}$ measurements were madewith Whatman-type CF pH 0-14indicator paper strips. Inert atmosphereoperations were conducted under nitrogen passed through a Drierite drying tube in oven- or flamedried glassware. Anhydrous tetrahydrofuran (THF) was distilled first from cal cium hydride and then from potassium; anhydrous ether was distilled from potassium. Triethylamine and methylene chloride were purified by distillation from calcium hydride. Diisopropylethylamine (DIEA) and DMF were dried over $3-\AA \AA$ molecular sieves. LHMDS (lithium hexamethyldisilazide, $1.0 \mathrm{M}$ in THF) was purchased from Aldrich Chemical Co. HATU (N-[(dimethylamino)-1H-1,2,3triazolo[4,5-b]pyridin-1-ylmethylene]-N-methylmethanaminiumhexafluorophosphate $\mathrm{N}$-oxide) was purchased from PerSeptive BiosystemsInc. Reagents were used as purchased from Aldrich, Sigma-Aldrich, or Acros unless stated otherwise.

N-Acetyl-ADDA Methyl Ester (3). TFA (2 mL) was added to $31 \mathrm{mg}(0.70 \mathrm{mmol})$ of N-Boc-ADDA methyl ester (1) in a flask. After $1 \mathrm{~h}$, the TFA was removed under vacuum, and the residue was concentrated threetimes from tolueneto remove the TFA. The resulting oil (2) was dissolved in $2.5 \mathrm{~mL}$ of freshly distilled $\mathrm{CH}_{2} \mathrm{Cl}_{2}$ and cooled to $0{ }^{\circ} \mathrm{C}$. Anhydrous triethylamine $(28 \mathrm{mg}, 0.28 \mathrm{mmol})$ was added to the solution, followed by freshly distilled acetic anhydride $(0.141 \mathrm{~g}, 1.39$ mmol). After $1 \mathrm{~h}$, saturated $\mathrm{NH}_{4} \mathrm{Cl}(5 \mathrm{~mL})$ was added. The mixture was stirred for $20 \mathrm{~min}$ at $0{ }^{\circ} \mathrm{C}$ and then extracted with EtOAc $(3 \times 5 \mathrm{~mL})$. The extract was washed successively with $50 \%$ saturated $\mathrm{NH}_{4} \mathrm{Cl}, 50 \%$ saturated $\mathrm{NaCO}_{3}$, and brine, then dried $\left(\mathrm{MgSO}_{4}\right)$, and concentrated under vacuum to give a white solid. Thissolid was purified by flash chromatography (EtOAc-hexane, 1:1) to give N-acetyl-ADDA methyl ester (3) ( $25 \mathrm{mg}, 93 \%$ ) as a white solid. TLC $\mathrm{R}_{\mathrm{f}} 0.23$ (EtOAc-hexane, 2:3). IR (thin film): $3330,2919,1731,1654,1454 \mathrm{~cm}^{-1} .{ }^{1} \mathrm{H}$ NMR $\left(\mathrm{CDCl}_{3}, \delta\right): 0.99(3 \mathrm{H}, \mathrm{d}, \mathrm{J}=6.5 \mathrm{~Hz}), 1.20(3 \mathrm{H}, \mathrm{d}, \mathrm{J}=7$ $\mathrm{Hz}), 1.57(3 \mathrm{H}, \mathrm{s}), 2.02(3 \mathrm{H}, \mathrm{s}), 2.58(1 \mathrm{H}, \mathrm{ddq}, \mathrm{J}=6,6.5,10 \mathrm{~Hz})$, $2.67(1 \mathrm{H}, \mathrm{dd}, \mathrm{J}=7.5,14 \mathrm{~Hz}), 2.78(3 \mathrm{H}, \mathrm{m}), 2.79(1 \mathrm{H}, \mathrm{dd}, \mathrm{J}=$ 5, $13.5 \mathrm{~Hz}), 3.17(1 \mathrm{H}, \mathrm{ddd}, \mathrm{J}=5,6,7 \mathrm{~Hz}), 3.21(3 \mathrm{H}, \mathrm{s}), 3.65$ $(3 \mathrm{H}, \mathrm{s}), 4.71(1 \mathrm{H}, \mathrm{ddd}, \mathrm{J}=4.5,5,5.5 \mathrm{~Hz}), 5.37(1 \mathrm{H}, \mathrm{d}, \mathrm{J}=9.5$ $\mathrm{Hz}), 5.42(1 \mathrm{H}, \mathrm{dd}, \mathrm{J}=6.5,15.5 \mathrm{~Hz}), 6.18(1 \mathrm{H}, \mathrm{d}, \mathrm{J}=15.5 \mathrm{~Hz})$, $6.40(1 \mathrm{H}, \mathrm{d}, J=9 \mathrm{~Hz}), 7.25-7.15(5 \mathrm{H}, \mathrm{m})$. HRMS $(\mathrm{m} / \mathrm{z})$ : $388.2505(\mathrm{M}+\mathrm{H})^{+}$calcd for $\mathrm{C}_{23} \mathrm{H}_{34} \mathrm{NO}_{4}, 388.2488$.

N-Acetyl-ADDA (4). The methyl ester from the previous step (3) (22 mg, $0.057 \mathrm{mmol})$ in THF (2 mL) was hydrolyzed by addition to $\mathrm{LiOH}(1 \mathrm{M}, 0.57 \mathrm{~mL}, 0.57 \mathrm{mmol})$. After being stirred for $22 \mathrm{~h}$, the mixture clarified. Water $(5 \mathrm{~mL})$ was added, and the product was washed with hexane $(2 \times 5 \mathrm{~mL})$. The combined hexane washes were back-extracted with water ( 3 $\times 5 \mathrm{~mL}$ ). The combined aqueous extracts were acidified with $\mathrm{NaHSO}_{4}(1 \mathrm{M})$ and extracted with $\mathrm{CH}_{2} \mathrm{Cl}_{2}(3 \times 5 \mathrm{~mL})$. The 
$\mathrm{CH}_{2} \mathrm{Cl}_{2}$ extracts were washed with brine, filtered, and concentrated to give $\mathrm{N}$-acetyl-ADDA (4) $(23 \mathrm{mg})$ as an oil that was used without purification. TLC $\mathrm{R}_{\mathrm{f}} 0.34$ (HOACEtOAc-hexane, 1:49:50). IR (thin film): 3295 br, 2923, 1713, $1640 \mathrm{~cm}^{-1}$. ${ }^{1} \mathrm{H} \mathrm{NMR}\left(\mathrm{CDCl}_{3}, \delta\right): 0.99(3 \mathrm{H}, \mathrm{d}, \mathrm{J}=6.5 \mathrm{~Hz}), 1.25$ $(3 \mathrm{H}, \mathrm{d}, \mathrm{J}=7 \mathrm{~Hz}), 1.58(3 \mathrm{H}, \mathrm{s}), 2.02(3 \mathrm{H}, \mathrm{s}), 2.57(1 \mathrm{H}, \mathrm{ddq}, \mathrm{J}$ $=6.5,6.5,9.5 \mathrm{~Hz}), 2.65(1 \mathrm{H}, \mathrm{dd}, \mathrm{J}=7.5,14 \mathrm{~Hz}), 2.76(3 \mathrm{H}, \mathrm{m})$, $2.77(1 \mathrm{H}, \mathrm{dd}, \mathrm{J}=5,13 \mathrm{~Hz}), 3.17(1 \mathrm{H}, \mathrm{ddd}, \mathrm{J}=5,6.5,6.5 \mathrm{~Hz})$, $3.21(3 \mathrm{H}, \mathrm{s}), 4.71(1 \mathrm{H}, \mathrm{ddd}, \mathrm{J}=5,6,10 \mathrm{~Hz}), 5.37(1 \mathrm{H}, \mathrm{d}, \mathrm{J}=$ $9.5 \mathrm{~Hz}), 5.45(1 \mathrm{H}, \mathrm{dd}, \mathrm{J}=6.5,15.5 \mathrm{~Hz}), 6.18(1 \mathrm{H}, \mathrm{d}, \mathrm{J}=15.5$ $\mathrm{Hz}), 6.37(\mathrm{lH}, \mathrm{d}, \mathrm{J}=9.5 \mathrm{~Hz}), 7.25-7.15(5 \mathrm{H}, \mathrm{m}) . \mathrm{HRMS}(\mathrm{m} / \mathrm{z})$ : $374.2325(\mathrm{M}+\mathrm{H})^{+}$calcd for $\mathrm{C}_{22} \mathrm{H}_{32} \mathrm{NO}_{4}, 374.2331$.

N-Acetyl-ADDA-D-Alanyl Methyl Ester (5). N-AcetylADDA (4) (9 mg, $0.024 \mathrm{mmol})$ in DMF $(0.6 \mathrm{~mL})$ was added to $\mathrm{D}$-alanine methyl ester hydrochloride $(17 \mathrm{mg}, 0.12 \mathrm{mmol}$ ) and HATU (14 mg, $0.036 \mathrm{mmol})$. The resulting solution was cooled to $0^{\circ} \mathrm{C}$, and collidine ( $41 \mathrm{mg}, 0.34 \mathrm{mmol}$ ) was added. Thesolution was stirred at $0^{\circ} \mathrm{C}$ for $2 \mathrm{~h}$, then warmed to room temperature, and stirred overnight. Water $(5 \mathrm{~mL})$ was added, and the product was extracted with EtOAc $(2 \times 5 \mathrm{~mL})$. The extract was washed successively with saturated $\mathrm{NaHCO}_{3}$, water, $1 \mathrm{M} \mathrm{NaHSO}_{4}$, water, and brine, and then dried $\left(\mathrm{MgSO}_{4}\right)$ and concentrated under vacuum. Flash chromatography (EtOAc-hexane, 4:1) gave $\mathrm{N}$-acetyl-ADDA-D-alanyl methyl ester (5) (8 mg, 73\%) as a white solid. TLC $R_{f} 0.17$ (EtOAchexane, 3:2). IR (thin film): 3284, 3067, 2923, 1743, 1650, $1542 \mathrm{~cm}^{-1} .{ }^{1} \mathrm{H} N M R\left(\mathrm{CDCl}_{3}, \delta\right): 0.99(3 \mathrm{H}, \mathrm{d}, \mathrm{J}=6.5 \mathrm{~Hz}), 1.23$ $(3 \mathrm{H}, \mathrm{d}, \mathrm{J}=7 \mathrm{~Hz}), 1.35(3 \mathrm{H}, \mathrm{d}, \mathrm{J}=7 \mathrm{~Hz}), 1.58(3 \mathrm{H}, \mathrm{s}), 2.04(3 \mathrm{H}$, s), $2.52(1 \mathrm{H}, \mathrm{dq}, \mathrm{J}=4,7 \mathrm{~Hz}), 2.59(1 \mathrm{H}, \mathrm{ddq}, \mathrm{J}=6.5,7,9.5 \mathrm{~Hz})$, $2.68(1 \mathrm{H}, \mathrm{dd} J=7.5,14 \mathrm{~Hz}), 2.81(1 \mathrm{H}, \mathrm{dd}, \mathrm{J}=4.5,14 \mathrm{~Hz}), 3.19$ $(1 \mathrm{H}, \mathrm{ddd}, \mathrm{J}=5,7,7 \mathrm{~Hz}), 3.22(3 \mathrm{H}, \mathrm{s}), 3.75(3 \mathrm{H}, \mathrm{s}), 4.55(1 \mathrm{H}$, $\mathrm{dq}, \mathrm{J}=7,7 \mathrm{~Hz}), 4.62(1 \mathrm{H}, \mathrm{m}), 5.39(1 \mathrm{H}, \mathrm{d}, \mathrm{J}=9.5 \mathrm{~Hz}), 5.45$ $(1 \mathrm{H}, \mathrm{dd}, \mathrm{J}=6.5,15.5 \mathrm{~Hz}), 6.18(1 \mathrm{H}, \mathrm{d}, \mathrm{J}=15.5 \mathrm{~Hz}), 6.23(1 \mathrm{H}$, $\mathrm{d}, \mathrm{J}=7 \mathrm{~Hz}), 7.05(1 \mathrm{H}, \mathrm{d}, \mathrm{J}=9 \mathrm{~Hz}), 7.27-7.17(5 \mathrm{H}, \mathrm{m})$. HRMS $(\mathrm{m} / \mathrm{z}): 459.2869(\mathrm{M}+\mathrm{H})^{+}$calcd for $\mathrm{C}_{26} \mathrm{H}_{39} \mathrm{~N}_{2} \mathrm{O}_{5}, 459.2859$.

N-Acetyl-ADDA-D-Alanine (6). To N-acetyl-ADDA-Dalanyl methyl ester (5) (5 mg, $0.011 \mathrm{mmol})$ in THF ( $2 \mathrm{~mL})$ was added $1 \mathrm{M} \mathrm{LiOH}(0.10 \mathrm{~mL}, 0.10 \mathrm{mmol})$. After $50 \mathrm{~min}$, water was added, and the solution was washed with diethyl ether $(2 \times 5 \mathrm{~mL})$. The ethereal extracts were back-extracted with water $(3 \times 3 \mathrm{~mL})$, and the aqueous fractions were combined and adjusted to $\mathrm{pH} 3$ by addition of saturated citric acid. The aqueous solution was extracted with EtOAc $(2 \times 5 \mathrm{~mL})$, and the EtOAc extracts were washed with water $(2 \times 5 \mathrm{~mL})$ and brine $(5 \mathrm{~mL})$, dried $\left(\mathrm{MgSO}_{4}\right)$, and concentrated under vacuum. The resulting solid was purified by preparative reversedphase HPLC ( $\mathrm{MeOH}$-aqueousTFA (0.2\%), 7:3; $\mathrm{R}_{t}$ of product, $15.7 \mathrm{~min}$ ) to give $\mathrm{N}$-acetyl-ADDA-D-alanine (6) (4 mg, 85\%) as a white solid. TLC $\mathrm{R}_{\mathrm{f}} 0.36\left(\mathrm{HOAC}-\mathrm{MeOH}-\mathrm{CH}_{2} \mathrm{Cl}_{2}, 1: 10\right.$ : 89). IR (thin film): $3288 \mathrm{br}, 2937,1720,1658,1632 \mathrm{~cm}^{-1} .{ }^{1} \mathrm{H}$ NMR (DMSO- $\left.d_{6}, \delta\right): 0.94\left(3 \mathrm{H}, d_{,} J=7.0 \mathrm{~Hz}\right), 0.96(3 \mathrm{H}, \mathrm{d}, \mathrm{J}$ $=7.0 \mathrm{~Hz}), 1.19(3 \mathrm{H}, \mathrm{d}, \mathrm{J}=7.0 \mathrm{~Hz}), 1.52(3 \mathrm{H}, \mathrm{s}), 1.82(3 \mathrm{H}, \mathrm{s})$, $2.63(1 \mathrm{H}, \mathrm{dd}, \mathrm{J}=7.0,14.0 \mathrm{~Hz}), 2.73(1 \mathrm{H}, \mathrm{dd}, \mathrm{J}=5.0,14.0 \mathrm{~Hz})$, $3.16(3 \mathrm{H}, \mathrm{s}), 3.22(1 \mathrm{H}, \mathrm{ddd}, \mathrm{J}=5.5,5.5,6.5 \mathrm{~Hz}), 4.19(1 \mathrm{H}, \mathrm{dq}$, $J=7.0,7.5 \mathrm{~Hz}), 4.40(1 \mathrm{H}, \mathrm{m}), 5.38(1 \mathrm{H}, \mathrm{d}, \mathrm{J}=10.0 \mathrm{~Hz}), 5.44$ $(1 \mathrm{H}, \mathrm{dd}, \mathrm{J}=6.5,16.0 \mathrm{~Hz}), 6.05(1 \mathrm{H}, \mathrm{d}, \mathrm{J}=16.0 \mathrm{~Hz}), 7.17(3 \mathrm{H}$, $\mathrm{d}, \mathrm{J}=7.5 \mathrm{~Hz}), 7.25(2 \mathrm{H}, \mathrm{t}, \mathrm{J}=7.5 \mathrm{~Hz}), 7.60(1 \mathrm{H}, \mathrm{d}, \mathrm{J}=9.0 \mathrm{~Hz})$, $8.01(1 \mathrm{H}, \mathrm{d}, \mathrm{J}=7.0 \mathrm{~Hz})$. FAB MS (m/ z): $445.2695(\mathrm{M}+\mathrm{H})^{+}$ calcd for $\mathrm{C}_{25} \mathrm{H}_{37} \mathrm{~N}_{2} \mathrm{O}_{5}, 445.2702$.

N-Hemiglutaryl-ADDA Methyl Ester (7). N-Boc-ADDA methyl ester (1) ( $7 \mathrm{mg}, 0.016 \mathrm{mmol}$ ) was added to TFA ( $1 \mathrm{~mL}$, $15 \mathrm{mmol}$ ) and stirred at ambient temperaturefor 0.5h. Excess TFA was removed under vacuum, and the resulting TFA salt was treated threetimes with toluene $(2 \mathrm{~mL})$ and concentrated under vacuum. The resulting oil was suspended in $\mathrm{CH}_{2} \mathrm{Cl}_{2}$ $(0.5 \mathrm{~mL})$ and treated with glutaric anhydride $(3.5 \mathrm{mg}, 0.03$ $\mathrm{mmol})$. After being stirred at ambient temperature for $1 \mathrm{~h}$, the solution was partitioned between $\mathrm{CH}_{2} \mathrm{Cl}_{2}$ and saturated $\mathrm{NH}_{4} \mathrm{Cl}$ (10 mL each). The organic layer was washed with saturated $\mathrm{NaHSO}_{4}(2 \times 10 \mathrm{~mL})$, dried $\left(\mathrm{Na}_{2} \mathrm{SO}_{4}\right)$, and con-
TABLE 1. Midpoint Titers, Determined as 1/Antiserum Dilution Giving $50 \%$ Maximum Absorbance, for Each Antiseruma ${ }^{a}$

$\begin{array}{ccc}\text { sheep no. } & \begin{array}{c}\text { immunogen } \\ \text { antibody titer }\end{array} \\ 813 & \text { BSA-ADDA } & 45000 \\ 814 & \text { BSA-ADDA } & 45000 \\ 815 & \text { BSA-ADDA } & 25000 \\ 823 & \text { CBSA-ADDA } & 100000 \\ 824 & \text { CBSA-ADDA } & 200000 \\ 825 & \text { CBSA-ADDA } & 100000 \\ 826 & \text { OVA-ADDA } & <1000 \\ 827 & \text { OVA-ADDA } & <1000 \\ 828 & \text { OVA-ADDA } & <1000\end{array}$

a Italicized entry corresponds to the antiserum of highest titer selected for further study.

centrated under vacuum. Purification by preparative TLC gave the anhydride as a white solid. This was suspended in EtOAc and washed with saturated $\mathrm{NaHCO}_{3}$. Theorganic layer was concentrated under vacuum, and the residue was purified by preparative TLC (EtOAc-hexane-HOAc, 70:29:1) to yield 7 as a colorless oil (3 mg, 42\% yield). IR (thin film): 3286, 2926, 1733, 1648, 1534, 1453, $1198 \mathrm{~cm}^{-1}$. ${ }^{1} \mathrm{H}$ NMR $(400 \mathrm{MHz}$, $\left.\mathrm{CDCl}_{3}, \delta\right): 1.01(3 \mathrm{H}, \mathrm{d}, \mathrm{J}=6.8 \mathrm{~Hz}), 1.22(3 \mathrm{H}, \mathrm{d}, \mathrm{J}=7.2 \mathrm{~Hz})$, $1.59(3 \mathrm{H}, \mathrm{s}), 2.00(2 \mathrm{H}, \mathrm{m}), 2.35(2 \mathrm{H}, \mathrm{t}, \mathrm{J}=7.6 \mathrm{~Hz}), 2.44(2 \mathrm{H}$, $\mathrm{t}, \mathrm{J}=7.2 \mathrm{~Hz}), 2.58(1 \mathrm{H}, \mathrm{m}), 2.67(1 \mathrm{H}, \mathrm{dd}, \mathrm{J}=7.6,14.0 \mathrm{~Hz})$, $2.79(2 \mathrm{H}, \mathrm{m}), 3.19(1 \mathrm{H}, \mathrm{m}), 3.22(3 \mathrm{H}, \mathrm{s}), 3.68(3 \mathrm{H}, \mathrm{s}), 4.71(1 \mathrm{H}$, $\mathrm{m}), 5.38-5.44(2 \mathrm{H}, \mathrm{m}), 6.18(1 \mathrm{H}, \mathrm{d}, \mathrm{J}=15.6 \mathrm{~Hz}), 6.56(1 \mathrm{H}$, $\mathrm{d}, \mathrm{J}=9.2 \mathrm{~Hz}), 7.17-7.28(5 \mathrm{H}, \mathrm{m})$. HRMS (FAB Nal/ NBA, $\mathrm{m} / \mathrm{z}): 460.2708(\mathrm{M}+\mathrm{H})^{+}$calcd for $\mathrm{C}_{26} \mathrm{H}_{38} \mathrm{NO}_{6}, 460.2699$.

Conjugation of N-Acetyl-ADDA-D-Alanine (6) to BSA, CBSA, and OVA. BSA (10.6 mg), CBSA (10.0 mg), and OVA (8.3 $\mathrm{mg}$ ) were each dissolved in phosphate-buffered saline, $\mathrm{pH}$ 7.6 (PBS) (1000 $\mu \mathrm{L}$ ). N,N-Carbonyldiimidazole (19.81 mg, 0.12 $\mathrm{mmol})$ was dissolved in dry DMF $(500 \mu \mathrm{L})$, and a portion of thesolution ( $100 \mu \mathrm{L}$ ) was added to $\mathrm{N}$-acetyl-ADDA-D-alanine $(1.0 \mathrm{mg}, 2.2 \mu \mathrm{mol}$ ) and allowed to stand for $90 \mathrm{~min}$. DMF was added to each of the protein solutions (BSA, $260 \mu \mathrm{L} ; \mathrm{CBSA}$, $260 \mu \mathrm{L}$; OVA, $280 \mu \mathrm{L}$ ) just prior to addition of the activated ADDA derivative. The solution of the activated ADDA derivative was then added to the protein solutions ( $40 \mu \mathrm{L}$ each to the BSA and CBSA, $20 \mu \mathrm{L}$ to the OVA), and the conjugation reaction was allowed to proceed at $4{ }^{\circ} \mathrm{C}$ for 16 $\mathrm{h}$. The resulting conjugates were repeatedly diluted and then concentrated by ultrafiltration (Filtron centrifugal ultrafiltration tubes, $10 \mathrm{kDa}$ cutoff) until the calculated dilution of unretained low molecular compounds was > 10 (6).

Conjugation of N-Hemiglutaryl-ADDA Methyl Ester (7) to OVA. A solution of $\mathrm{N}, \mathrm{N}^{\prime}$-carbonyldiimidazole $(0.46 \mathrm{mg})$ in dryDMF $(100 \mu \mathrm{L})$ was added, with swirling, to N-hemiglutarylADDA methyl ester (7) $(0.27 \mathrm{mg})$. The solution was allowed to stand at ambient temperature for $50 \mathrm{~min}$ and then added to a solution of OVA (11.14 mg) in PBS $(1 \mathrm{~mL})$ at $4{ }^{\circ} \mathrm{C}$ with stirring. The solution became turbid and DMSO $(200 \mu \mathrm{L})$ was added to aid solubility of the active ester. After being stirred at $4{ }^{\circ} \mathrm{C}$ overnight, the protein solution was desalted on a polyamide size-exclusion column (Econo-Pac 10DG, BioRad) accordingto themanufacturers instructions. The eluted protein was then repeatedly diluted and then concentrated by ultrafiltration (Filtron centrifugal ultrafiltration tubes, 10 $\mathrm{kDa}$ cutoff) until the calculated dilution of unretained low molecular compounds was $>10^{3}$ to give OVA-ADDA-HG.

Immunizations. Groups of three sheep were immunized with $\mathrm{N}$-acetyl-ADDA-D-alanine (6) coupled to either BSA (BSA-ADDA), CBSA (cBSA-ADDA), or OVA (OVA-ADDA), respectively (Table 1 ). For primary immunizations, immunogens were prepared as water-in-oil suspensions by injecting the conjugate, dissolved in PBS (1 mg of protein in $1 \mathrm{~mL}$ ), into $2.5 \mathrm{~mL}$ Freund's complete adjuvant, followed by vortex 
mixing. Immunogens for secondary and subsequent immunizations (up to eight boosts) were administered as emulsions in Freund's incomplete adjuvant, prepared as above.

The immunogen emulsion $(0.5 \mathrm{~mL})$ was administered intramuscularly into the semitendinosismuscle, $0.25 \mathrm{~mL}$ per hind leg via a 20 -gauge needle. Test bleeds $(10 \mathrm{~mL}$ Vacutainer no. 366430, Becton Dickinson, Franklin Lakes, NJ) weretaken from the jugular vein 14 days after the third and subsequent immunizations, and antibody titers were determined by ELISA. Larger volumes of blood for antisera production were obtained by venipuncture and collected into blood bags (blood bag 4R0001, Baxter, Deerfield, IL) under negative pressure, from sheep identified as having high titers. A series of three injections at four-weekly intervals was followed by a rest period, with subsequent boosts at no less than fourweekly intervals.

All animal manipulations were performed under the authority of the AgResearch Ruakura Animal Ethics Committee, in accordance with the New Zealand Animal Protection (Codes of Ethical Conduct) Regulations 1987, and Animals Protection Act (1960 and subsequent amendments).

ELISA. ELISA plates (NUNC MaxiSorp 1 no. 439454, Denmark) were coated overnight with OVA-ADDA-hemiglutaryl (OVA-ADDA-HG) or BSA-ADDA conjugate in $0.05 \mathrm{M}$ sodium carbonate buffer at $\mathrm{pH} 9.6$ (75 $\mu \mathrm{L} /$ well, $2.5 \mu \mathrm{g} / \mathrm{mL}$ ) at $20^{\circ} \mathrm{C}$. Unbound material was removed by aspiration. After being washed with PBS, additional binding sites were blocked by incubation with OVA or BSA, respectively ( $1 \% \mathrm{w} / \mathrm{v}, 300$ $\mu \mathrm{L}, 1 \mathrm{~h}, 20-25^{\circ} \mathrm{C}$ ). Plates were washed three times with PBS and used immediately or stored at $4^{\circ} \mathrm{C}$ for up to 7 days. In theassay, sample or standard $(50 \mu \mathrm{L})$ were added to the wells together with antiserum $(50 \mu \mathrm{L}$, at appropriate dilution, e.g., AB824 at $1 / 200000$ ). After incubation at $20-25^{\circ} \mathrm{C}$ for $2 \mathrm{~h}$, wells were washed twice with PBS containing 0.05\% Tween 20 (PBST) and twicewith PBS. Anti-sheep secondary antibody (ICN/Cappel rabbit-anti-sheep-HRP) (100 $\mu \mathrm{L}$, dilution 1/6000) was then added to the wells and incubated for $2 \mathrm{~h}$. Subsequently, wells were aspirated and washed twice with PBST and twice with PBS. Substrate solution (100 $\mu \mathrm{L}$ ), prepared by addition of TMB stock $(110 \mu \mathrm{L}, 10 \mathrm{mg} / \mathrm{mL}$ in DMSO) to sodium acetate buffer (11 mL, $0.1 \mathrm{M}, \mathrm{pH} 5.5$ ) containing $0.005 \% \mathrm{H}_{2} \mathrm{O}_{2}$, was added and incubated for 15 min. The reaction was stopped by addition of $\mathrm{H}_{2} \mathrm{SO}_{4}(50 \mu \mathrm{L}$, $2 \mathrm{M}$ ), and absorbance was determined with a microplate spectrophotometer at $450 \mathrm{~nm}$.

To detect matrix effects, ELISA standards and samples were diluted with the following matrixes: (a) PBS, (b) river water (Waikato River, New Zealand), and (c) tap water (Hamilton, New Zealand). Duplicates were then analyzed over a dilution range spanning 6 orders of magnitude.

Assay Characterization. Optimal concentrations of assay reagents were determined empirically by checkerboard titrations. Assay standard curves were calculated using Logit transformation of the data. The assay working range was defined as the linear region at $20-80 \%$ of maximum absorbance. Cross-reactivities in the assay of the microcystin congeners MC-LR, -RR, -YR, -LW, -LF, dmMC-LR, dmMC$\mathrm{RR}$, and nodularin (Figure 1) were calculated from the molar concentration of analogue giving $50 \%$ inhibition $\left(\mathrm{I}_{50}\right)$ of the binding of the serum to the protein-ADDA solid phase and are expressed relative to the $\mathrm{I}_{50}$ for MC-LR.

Extraction of Water Samples and Assay for the Activity of Ser/Thr Protein Phosphatases-1 and -2A. Organic extraction of the water and bloom samples from lakes and water treatment plants of Switzerland, preparation of [32P]phosphorylase a and the PP assay were performed as previously described in theliterature (6, 7). Extracellular toxins were harvested from the filtrates by solid-phase extraction (SPE), and the toxins were eluted with methanol. Algal cells were harvested by filtration, and the intracellular toxinswere extracted with by sonication in methanol, the methanol was evaporated, and the toxins were harvested by SPE as above. Detailed descriptions of the samples, the extraction, and the analytical methods and detailed analytical results are being published elsewhere (Höger et al., submitted for publication in Environ. Sci. Technol.).

\section{Results and Discussion}

Most previous immunoassays for microcystins $(22,25,27)$ were based on antibodies raised against MC-LR, coupled via its carboxyl groups to either BSA, OVA, or keyhole limpet haemocyanin $(K L H)$ in the presence of EDAC. MC-LR contains two carboxyl groups and is thus capable of semirandom "shotgun" and multivalent coupling to the carrier proteins. Furthermore, as microcystins are cyclic heptapeptides and nodularins are cyclic pentapeptides, the actual epitope(s) for antibody production provided by coupling of MC-LR or nodularin to proteins are difficult to control or even define. These factors and the fact that therearecurrently more than 60 known microcystin and nodularin congeners (35) largely explain why antibodies raised against microcystin$\mathrm{LR}$-protein conjugates have major limitations with regard to cross-reactivity with other microcystin and/ or nodularin analogues $(22,26)$. This is a major constraint in their routine use for analysis and quantitation of cyanobacterial cyclic peptide toxins in drinking water. In contrast, the presence of $6 \mathrm{E}-\mathrm{ADDA}$ (Figure 2 ) in at least $80 \%$ of the known strongly toxic microcystin and nodularin congeners providesa unique opportunity to use 6E-ADDA as the epitope for antibody recognition. Such an antibody ought to recognize virtually all thetoxic microcystins and nodularins with approximately equal sensitivity, regardless of their specific amino acid composition. Moreover, an assay based on such antibodies should be able to recognize the linear microcystins and nodularins that can result from microbial degradation (hydrolysis) of these cyclic peptides by microcystinases (37). This ability is of major importance because linear tetra(ADDA-Glu-M dha-Ala-OH) and hepta-(acydo-MC-LR) peptides arising from degradation of MC-LR are also potent inhibitors of protein phosphatases (with $\mathrm{IC}_{50}$ values of 12 and $95 \mathrm{nM}$, respectively) (37). These degradation products, although less toxic than MC-LR $\left(I_{50}=0.6 \mathrm{nM}\right)$, therefore have the potential to induce acute or chronic effects similar to those of microcystins and nodularins. However, these degradation products, although of importance for human risk assessment, would most likely not be recognized by currently available monoclonal or polyclonal antibodies. In contrast, detection of such degradation products is to be expected by an antibody that specifically recognizes $6 \mathrm{E}-$ ADDA. Consequently, a method was developed for synthesizing ADDA derivatives (haptens) that could be coupled to carrier proteins such as BSA, CBSA, or OVA.

A methyl ester of a tertiary butoxycarbonyl-protected ADDA precursor, N-Boc-ADDA methyl ester (1), was synthesized (Figure 2) using established methodology (34). Deprotection, followed by acetylation, ester hydrolysis, coupling with alanine methyl ester, and finally, ester hydrolysis afforded $\mathrm{N}$-acetyl-ADDA-D-alanine (6). This was reacted with $\mathrm{N}, \mathrm{N}$-carbonyldiimidazole to form the activated alanyl ester, which was then coupled to BSA, CBSA, and OVA to afford protein conjugates containing a structurally intact ADDA group.

Analysis of antibody titers (Table 1 ) indicated that sheep immunized with OVA-ADDA responded only weakly but that a strong immune response was generated by both BSA-ADDA and CBSA-ADDA, with CBSA-ADDA giving the best response. Titers were defined as the reciprocal of serum dilution giving $50 \%$ maximum absorbance in the indirect ELISA. The serum from sheep 824, henceforth referred to as polyclonal antibody 


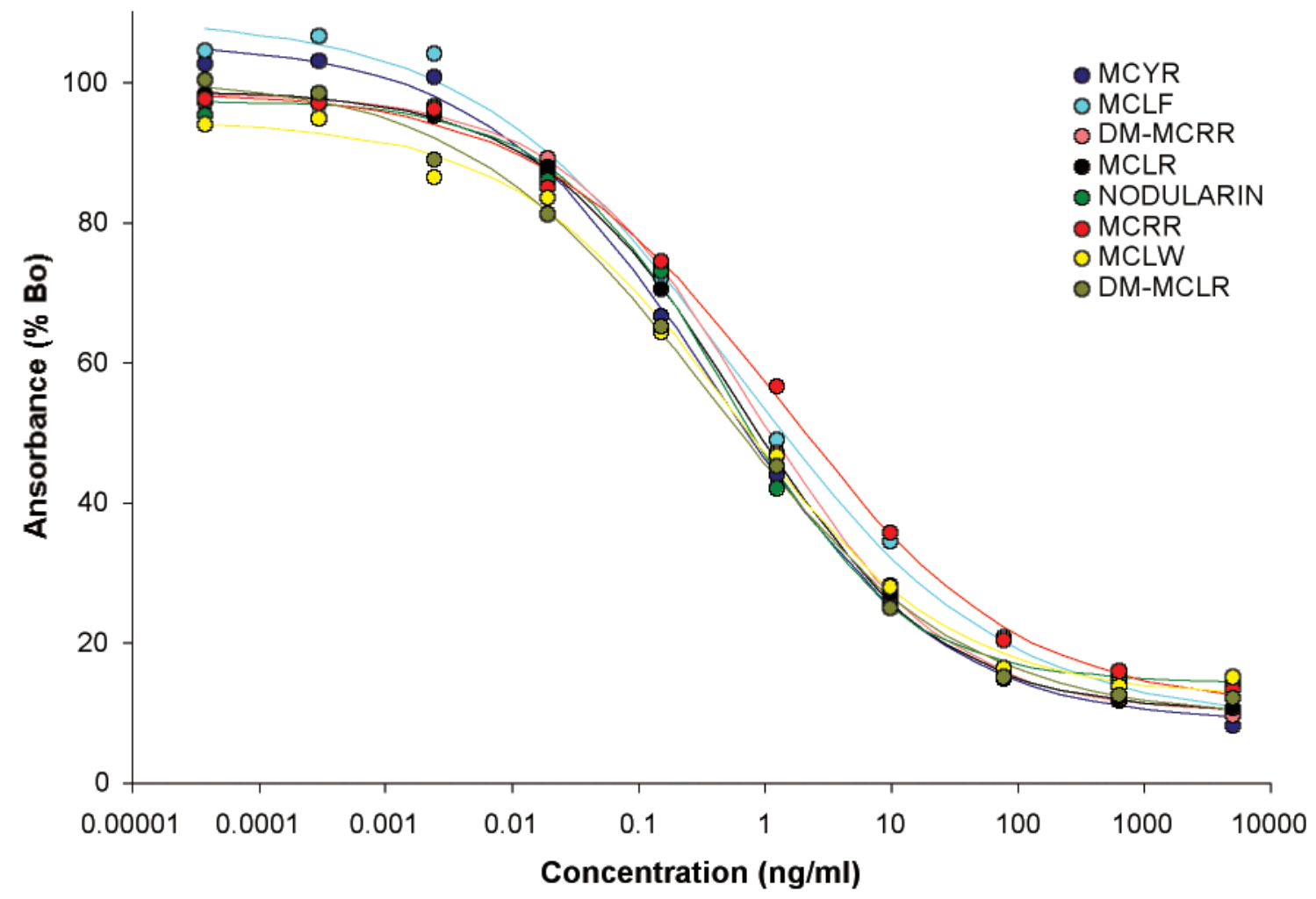

FIGURE 3. cELISA standard curves for cyanobacterial cyclic peptide toxin congeners. Data are show $n$ without standard error of mean of the individual congener values for improved clarity of the figure.

824 (AB824), had the highest titer as well as the highest sensitivity when tested with OVA-ADDA-HG-coated 96-well plates both in an indirect ELISA under limiting antibody conditions and in a preliminary competitiveELISA (data not shown). Therefore, AB824 was chosen for further characterization of sensitivity and congener cross-reactivity.

Competition ELISAs (cELISA) were set up using BSA-ADDA and OVA-ADDA-HG as plate coaters. In view of the low titer of OVA-immunized animals and the high background observed in cELISA employing the BSA-ADDA coater, all further characterizations were carried out with OVA-ADDA$\mathrm{HG}$ as plate coater. The sensitivity and congener crossreactivity of AB824 to MC-LR, MC-RR, MC-YR, MC-LW, MCLF, dmMC-LR, dmMC-RR, and nodularin (Figure 1) was tested in the CELISA over a range of dilutions (Figure 3 ). Employing the conservative cutoff values of $20 \%$ and $80 \%$ maximum absorbance, the ELISA had limits of quantitation (LOQs) of $0.02-0.07 \mathrm{ng} / \mathrm{mL}$, with working ranges of up to 5-26 ng/ mL, depending on the congener (Figure 3, Table 2). As demonstrated in Table 2, the cross-reactivity among the congeners tested was excellent despite the problems of determining cross-reactivities in the absence of certified referencestandards for the congeners. Some of the deviation from $100 \%$ cross-reactivity can be explained by the facts that (i) all commercially available congener standards contained impurities (guaranteed purity $\geq 95 \%$ ) and (ii) others have found on reanalyzis that the actual quantities of thecongener supplied ranged between $\pm 20 \%$ of the quantity stated by the supplier (personal communications). As cross-reactivities were calculated on the toxin mass specified by the supplier, cross-reactivites between 80 and $120 \%$ are most likely not differentiable from $100 \%$.

However, as the difference in the free energy of binding associated with $50 \%$ cross-reactivity is very small, only minute conformational or steric interactions of the ADDA moiety could account for the more significant differences in cross-
TABLE 2. Cross-Reactivities, Limits of Quantitation, and Working Ranges of ELISA for Selected Cyanobacterial Cyclic Peptide Toxin Congeners

$\begin{array}{lclccc}\text { congener } & \begin{array}{c}\mathbf{l}_{80}{ }^{b} \\ (\mathbf{n g} / \mathrm{mL})\end{array} & \begin{array}{c}\text { working } \\ \text { range } \\ (\mathbf{n g} / \mathrm{mL})\end{array} & \text { MW } & \begin{array}{c}I_{50}{ }^{c} \\ (\mathbf{n M})\end{array} & \begin{array}{c}\text { cross-reactivity } \\ \text { relative to } \\ \text { MC-LR (\%) }\end{array} \\ \text { MC-LR } & 0.05 & 0.05-7.50 & 995.2 & 0.61 & 100 \\ \text { MC-RR } & 0.06 & 0.06-26.26 & 1038 & 1.22 & 50 \\ \text { MC-YR } & 0.02 & 0.02-6.87 & 1045 & 0.37 & 167 \\ \text { MC-LW } & 0.03 & 0.03-8.33 & 1025 & 0.52 & 118 \\ \text { MC-LF } & 0.02 & 0.02-15.14 & 986.2 & 0.57 & 108 \\ \text { dmMC-LR } & 0.02 & 0.02-8.76 & 981.2 & 0.39 & 157 \\ \text { dmMC-RR } & 0.07 & 0.07-9.05 & 1024 & 0.77 & 80 \\ \text { nodularin } & 0.06 & 0.06-4.5 & 825 & 0.61 & 100\end{array}$

${ }^{a}$ For structures, see Figure $1 .{ }^{b}$ Limit of quantitation. ${ }^{c} 50 \%$ inhibition of binding.

reactivity observed to some congeners. This is of course an even greater problem when theantibody epitope is in a more variable region of the molecule, as is the case for presently published antibodies raised against the completemicrocystin toxin conjugated to a protein carrier $(22,23,27,36,38)$.

The effect of sample matrix on assay performance was tested using PBS, water, and river water spiked with MC-YR. The concentration curves for all three matrixes are depicted in Figure 4 (Supporting Information and Höger et al., submitted for publication in Environ. Sci. Technol.) and reveal negligiblematrix effects over a concentration range spanning 4 orders of magnitude (see also Table 3). Thus, sample preparation may be omitted when using the cELISA for the analysis of relatively clean water samples.

The comparison of the intra-assay variability $(n=2-4$ repeats) of the competitive indirect ELISA with the PP assay $(16,17)$ using extractsfrom environmental and treated water samples from Swiss lakes and water treatment plants 


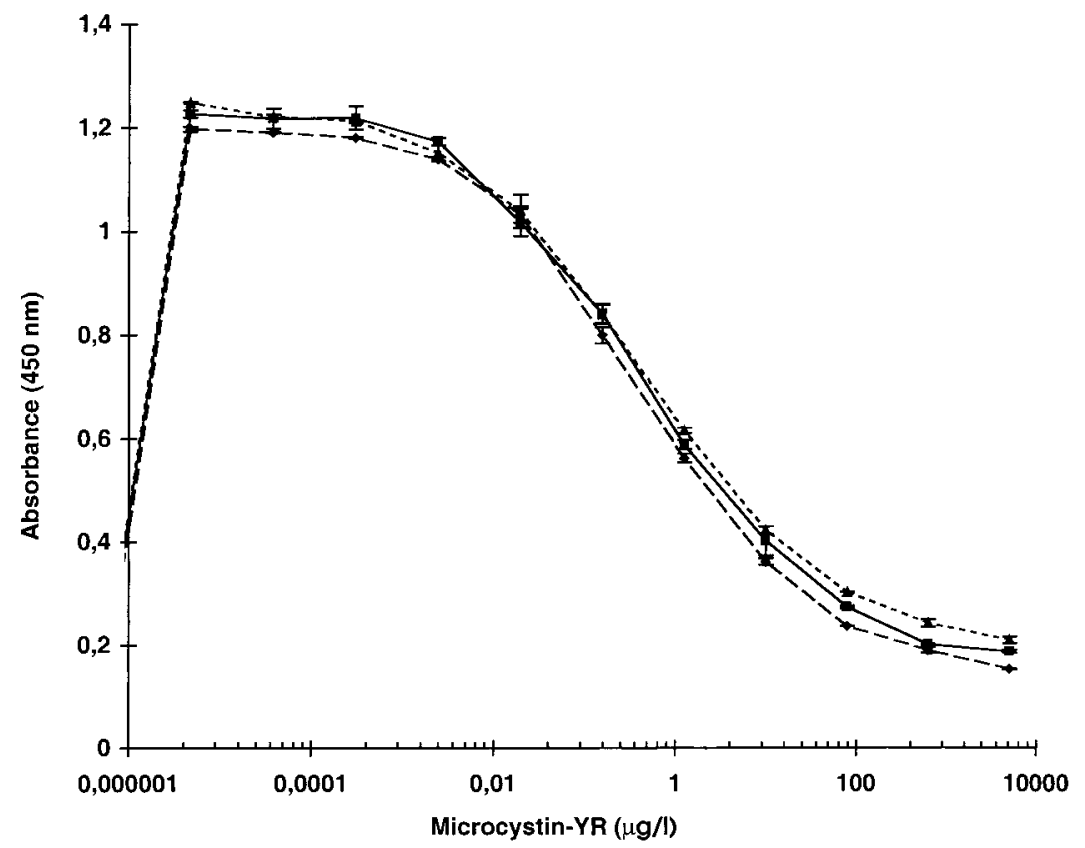

FIGURE 4. Negligible matrix effects in aqueous samples analyzed without sample pretreatment. Standard curves of microcystin-YR in tap $(-)$ and river water (--) coincided with standard curves in PBS (- - .

TABLE 3. Negligible Matrix Effects for Aqueous Samples Tested without Sample Pretreatment

\begin{tabular}{lc}
\multicolumn{1}{c}{ matrix } & $\mathbf{I C}_{\mathbf{5 0}}$ (\% of PBS) \\
PBS & 100 \\
tap water & 100 \\
river water & 97.7
\end{tabular}

demonstrated generally good correlation between the assays. TheELISA generally gavehigher values than the PPA but had 5 -fold better sensitivity with much better repeatability across a wide range of toxin concentrations (Supporting Information). The competitive indirect ELISA displays both the desired high cross-congener reactivity and high sensitivity. Indeed, all congeners tested to date are detected with high certainty (coefficient of variation $\ll 20 \%$ ), well below the 1 $\mathrm{ng} / \mathrm{mL}$ limit proposed by the WHO (12). In view of the fact that not only MC-LR but also almost all microcystin and nodularin congeners pose a serious human health risk and a major problem for providers of drinking water, methods for simple and reliable detection and quantification of all toxic cyclic peptides of cyanobacterial origin are of great interest.

The new cELISA allows detection and quantitation of numerous microcystin congeners, including nodularin, in drinking water at levels well below those proposed by the WHO, without any sample preparation or preconcentration steps. The integrative nature of ELISA sums the total microcystin content of the water, presenting the analyst with a value representing the total concentration of $M C$ and nodularin hepatotoxins. Although only a limited range of microcystin congeners have been tested to date, the data presented suggest that this CELISA is a valuable tool for routineanalysis of raw and drinking water. Indeed, theELISA has been used to quantify cyclic peptide toxins in river and reservoir water, cyanobacterial cultures, and blooms and has been employed for the detection of microcystin contamination in rivers and lakes in both New Zealand and Switzerland (data not presented). The wide cross-reactivity of the antibodies will also be useful in chemical and biochemical studies of cyanobacterial toxins, where applications such as immunoaffinity chromatography, HPLC-ELISA, and TLC-
ELISA should providepowerful tools for identification of novel toxin analogues, toxin metabolites, bioconjugates, and residues. Thesuccessful development of this assay highlights the importance of careful consideration of hapten design and selection in both the development of ELISAs for small molecules and the control of antibody specificity. It also illustrates theadvantages to begained from raisingantibodies against carefully chosen fragments of the analyte and the benefits of incorporating synthetic organic chemistry into the ELISA development process.

\section{Acknowledgments}

We thank Hugo Eng, UCl Department of Chemistry, for preparation of N-hemiglutaryl-ADDA methyl ester (7); Jussi Meriluoto, Åbo Akademi University (Turku, Finland), for supplying dmMC-LR and dmMC-RR; Stefan Höger and Bernhard Ernst, University of Konstanz (Germany), and Jan Sprosen, AgResearch (Hamilton, New Zealand), for assisting with testing of the ELISA. A.R.C. thanks the NIH for financial support (GM 57550).

\section{Supporting Information Available}

Figureshowing log-log plotfor intracellular and extracellular concentrations of microcystins measured by ELISA and PPA. This material is available free of charge via the Internet at http:// pubs.acs.org.

\section{Literature Cited}

(1) deSilva, E. D.; Williams, D. E.; Andersen, R. J.; Klix, H.; Holmes, C. F. B.; Allen, T. M. Tetrahedron Lett. 1992, 33, 1561-1564.

(2) Rinehart, K. L.; Namikoshi, M.; Choi, B. W. J. Appl. Phycol. 1994, 6, 159-176.

(3) Sivonen, K.; Jones, G. In Toxic Cyanobacteria in Water: A Guide to Their Public Health Consequences, Monitoring and Management; Chorus, I., Bartram, J., Eds.; E\&FN Spon: London, 1999; pp 41-111.

(4) Carmichael, W. W. Adv. Bot. Res. 1997, 27, 211-256.

(5) Schwimmer, M.; Schwimmer, D. In Algae, Man, and the Environment; Jackson, D. F., Ed.; Syracuse University Press: Syracuse, NY, 1968; pp 279-358. 
(6) Pouria, S.; de Andrade, A.; Barbosa, J.; Cavalcanti, R.; Barreto, V.; Ward, C.; Preiser, W.; Poon, G.; Neild, G.; Codd, G. Lancet 1998, 352, 21-26.

(7) Jochimsen, E. M.; Carmichael, W. W.; An, J. S.; Cardo, D. M.; Cookson, S. T.; Holmes, C. E.; Antunes, M. B.; de Melo Filho, D. A.; Lyra, T. M.; Barreto, V. S.; Azevedo, S. M.; Jarvis, W. R. N. Engl. J. Med. 1998, 338, 873-878.

(8) Teixeira, M.; Costa, M.; Carvalho, V.; Pereira, M.; Hage, E. Bull. Pan Am. Health Org. 1993, 27, 244-253.

(9) Harada, K.; Oshikata, M.; Uchida, H.; Suzuki, M.; Kondo, F.; Sato, K.; Ueno, Y.; Yu, S. Z.; Chen, G.; Chen, G. C. Nat. Toxins 1996, 4, 277-283.

(10) Ueno, Y.; Nagata, S.; Tsutsumi, T.; Hasegawa, A.; Watanabe, M. F.; Park, H.-D.; Chen, G.-C.; Chen, G.; Yu, S.-Z. Carcinogenesis 1996, 17, 1317-1321.

(11) Yu, S.-Z. In Primary Liver Cancer; Tang, Z. Y., Wu, M. C., Xia, S. S., Eds.; China Academic Publishers/Springer: New York, 1989; pp 30-37.

(12) WHO. Guidelines for Drinking-Water Quality. Addendum to Volume 2. Health Criteria and Other Supporting Information; World Health Organization: Geneva, Switzerland, 1998.

(13) Kuiper-Goodman, T.; Gupta, H.; Combley, H.; Thomas, B. H. In Toxic Cyanobacteria: Current Status of Research and Management; Steffensen, D. A., Nicholson, B. C., Eds.; Australian Centre for Water Quality Research: Salisbury, Australia, 1994; pp 67-73.

(14) Harada, K. In Toxic Microcystis; Watanabe, M., Harada, K., Carmichael, W., Fujiki, H., Eds.; CRC Press: Boca Raton, FL, 1996; pp 103-148.

(15) Meriluoto, J. Anal. Chim. Acta 1997, 352, 277-298.

(16) MacKintosh, C. In Protein Phosphorylation: A Practical Approach; Hardie, D. G., Ed.; Oxford University Press: Oxford, 1993; pp 197-229.

(17) Mountfort, D. O.; Kennedy, G.; Garthwaite, I.; Quilliam, M.; Truman, P.; Hanna, D. J. Toxicon 1999, 37, 909-922.

(18) Namikoshi, M.; Yuan, M.; Sivonen, K.; Carmichael, W. W. Rinehart, K. L.; Rouhiainen, L.; Sun, F.; Brittain, S.; Otsuki, A. Chem. Res. Toxicol. 1998, 11, 143-149.

(19) Sivonen, K.; Namikoshi, M.; Evans, W. R.; Carmichael, W. W.; Sun, F.; Rouhiainen, L.; Luukkainen, R.; Rinehart, K. L. Appl. Environ. Microbiol. 1992, 58, 2495-2500.

(20) Sivonen, K.; Namikoshi, M.; Evans, W. R.; Fardig, M.; Carmichael, W. W.; Rinehart, K. L. Chem. Res. Toxicol. 1992, 5, 464-469.

(21) Sivonen, K.; Namikoshi, M.; Evans, W. R.; Gromov, B. V.; Carmichael, W. W.; Rinehart, K. L. Toxicon 1992, 30, 14811485.
(22) Nagata, S.; Soutome, H.; Tsutsumi, T.; Hasegawa, A.; Sekijima, M.; Sugamata, M.; Harada, K.-i.; Suganuma, M.; Ueno, Y. Nat. Toxins 1995, 3, 78-86.

(23) Saito, S.; Nakano, Y.; Kushida, K.; Shirai, M.; Harada, K.-i.; Nakano, M. Microbiol. Immunol. 1994, 38, 389-392.

(24) Tsutsumi, T.; Nagata, S.; Yoshida, F.; Ueno, Y. J. Toxicol. Sci. 1998, 23 (Suppl.), 400.

(25) Ueno, Y.; Nagata, S.; Tsutsumi, T.; Hasegawa, A.; Yoshida, F.; Suttajit, M.; Mebs, D.; Pütsch, M.; Vasconcelos, V. Nat. Toxins 1996, 4, 271-276

(26) An, J.; Carmichael, W. W. Toxicon 1994, 32, 1495-1507.

(27) Chu, F. S.; Huang, X.; Wei, R. D.; Carmichael, W. W. Appl. Environ. Microbiol. 1989, 55, 1928-1933.

(28) McDermott, C. M.; Feola, R.; Plude, J. Toxicon 1995, 33, 1433 1442.

(29) Rinehart, K. L.; Harada, K.-i.; Namikoshi, M.; Chen, C.; Harvis, C. A.; Munro, M. H. G.; Blunt, J. W.; Mulligan, P. E.; Beasley, B. R.; Dahlem, A. M.; Carmichael, W. W. J. Am. Chem. Soc. 1988, 110, 8557-8558.

(30) Carmichael, W. W. J. Appl. Bacteriol. 1992, 72, 445-459.

(31) Harada, K.-i.; Matsuura, K.; Suzuki, M.; Watanabe, M. F.; Oishi, S.; Dahlem, A. M.; Beasley, V. R.; Carmichael, W. W. Toxicon 1990, 28, 55-64.

(32) Meriluoto, J.; Lawton, L.; Harada, K.-i. In Bacterial Toxins: Methods and Protocols; Holst, O., Ed.; Humana Press: Totowa, NJ, 2000; pp 65-87.

(33) Hermanson, G. T. Bioconjugate Techniques; Academic Press: San Diego, 1996

(34) Humphrey, J. M.; Aggen, J. B.; Chamberlin, A. R. J. Am. Chem. Soc. 1996, 118, 11759-11770.

(35) Chorus, I.; Bartram, J. Toxic Cyanobacteria in Water: A Guide to Their Public Health Consequences, Monitoring and Manage ment; E\&FN Spon: London, 1999.

(36) Chu, F. S.; Huang, X.; Wei, R. D. J. Assoc. Off. Anal. Chem. 1990 $73,451-456$

(37) Bourne, D. G.; Jones, G. J.; Blakeley, R. L.; Jones, A.; Negri, A P.; Riddles, P. Appl. Environ. Microbiol. 1996, 62, 4086-4094.

(38) Metcalf, J. S.; Bell, S. G.; Codd, G. A. Water Res. 2000, 34, 27612769. 